\title{
SOUNDNESS \& FEASIBILITY OF ADDITIONAL FLOOR ON EXISTING RC BUILDING WITH A COMPARATIVE STUDY ON STRENGTHENING MEASURES
}

\author{
Shruthi Asundi V ${ }^{1}$, R. G. Talasadar ${ }^{2}$ \\ ${ }^{1} P G$ Student, Department of Civil, BLDEA'S Dr. P G Halakatti College of Engineering \& Technology, Viayapur, \\ India. \\ shruthi.asundi@gmail.com \\ ${ }^{2}$ Prof., Department of Civil, BLDEA'S Dr. P G Halakatti College of Engineering \& Technology, Viayapur, India \\ rtalasadar@gmail.com
}

\begin{abstract}
Many RC structures are influenced by different adverse conditions, where the serviceability and structural capacity may be decreased. Some structural disorders may be observed due to inadequacy of reinforcement provided, strength of concrete or the difference in grade of concrete used during construction. This requires the application of strengthening measures. Hence the structure is thoroughly investigated for quality, strength of concrete and other design aspects. A major part of the investigation also involves the feasibility of one additional floor over the existing $R C$ structure where the deficiency of reinforcement is analyzed for the proposed additional load. The appropriate strengthening measures for the deficient RC members are presented based on the analysis of the structure and also considering the different site constraints.
\end{abstract}

Keywords - RC structure, structural disorder, feasibility, strengthening measures.

\section{INTRODUCTION}

Many RC structures are influenced by different adverse conditions which in turn show the deterioration of the structure. Lack of quality in concrete and standards of workmanship or construction supervision, and also factors like environmental influences can decrease the serviceability of the structure (e.g [2]). Thus the structure is left with the option either the demolition or the repair of the structure.

The existing RC building -"Prestige Excelsior" an IT campus, at Exora Business Park at Bangalore, comprises of Basement + Ground + nine upper floors. An organisation, intend to occupy the building for setting of their office and an additional floor in this existing building. On account of this, it was recommended to carry out structural evaluation of the building. This study involves the analytical investigation of the existing building for soundness and feasibility of one additional floor over the building(e.g[4]). In response to this, assessment tests were carried out and the durability issues in RC members were detected by NDT (e.g [1]).

Testing of concrete structures is often necessary to determine the suitability of the structures. Such testing should be conducted without causing any damage to the existing structures. This is nothing but Non Destructive Testing (NDT). The strength of concrete, surface hardness and absorption, reinforcement location, size and distance from the surface are known from NDT. Sometimes, testing of existing concrete structures is carried out by partially damaging the surface of the members of the structure. This is generally called semi destructive testing. However the surface is repaired after the test. For example, core test is considered to be a semi destructive test.

There are many NDT and semi destructive test methods which have been applied for the testing of hardened concrete. In the present project, the existing RC structure is tested by the following tests;

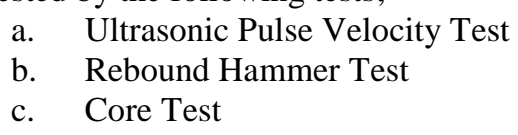

\subsection{Strengthening Measures}

Strengthening measures are nothing but the method of rehabilitating the deficient members of the existing RC or steel structure. Strengthening measures are carried out in order to achieve the required strength in $\mathrm{RC}$ or steel members of the structure. These are also intended to prevent the structure from demolition, instead bring it to the normalcy. There are various methods of strengthening measures which have been used for strengthening of different structural members. Some of the methods recommended for the members of existing building are concrete encasement, carbon fiber wrapping and steel plate bonding for RC columns, laminates for RC slabs, beams and drop regions. 


\section{EXPERIMENTAL STUDY}

\subsection{Physical Observations}

Following are the physical observations consequent to detailed inspection at various lelvels of the building :

1. Cracks were observed in screed concrete at few locations along the line of columns.

2. Presence of honeycombs and voids were observed in column, predominantly at lift interface especially at top region of column.

3. Presence of honeycombs and voids were observed in beams, sunken slab and at slab drop region at few locations.

4. Basement ceiling slab was observed to be punctured by a series of core holes ( $250 \mathrm{~mm}$ dia -5 to 6 holes), cutting the existing slab reinforcement to facilitate utilities.

5. Excessive accumulation of debris and waste materials was observed over the ground floor slab.

6. Presence of cracks was observed in few RC beams.

7. Presence of spalled or loose concrete was observed along the construction joint at few locations of construction joint.

8. Presence of separation cracks between wall and RC members was observed at few locations.

9. Patchup work was observed to be carried out on few RC columns and beams.

10. Exposure of rebar and presence of honeycombs/voids were observed in lift interface at beam column junctions at few floor levels.

\subsection{Evaluation Tests/Study}

Non-destructive tests to assess the quality/strength of in-situ concrete in RC members.

\section{a) Ultrasonic Pulse Velocity test(UPVT) on RC columns} and beams.

Ultrasonic Pulse Velocity test was carried out on RC columns and beams at randomly selected members in all the floors by forming uniform grids. From the results of the UPVT, the pulse velocity measured was varying in the range $3.5 \mathrm{~km} / \mathrm{sec}$ to $4.5 \mathrm{~km} / \mathrm{sec} \&$ above. From this, it is inferred that the quality grading of concrete in the tested RC columns and beams falls in the range of "Medium to Good concrete", as per IS:13311 - (Part-I)-1992-(Reaffirmed in 2013).

\section{b) Rebound Hammer test on RC slabs and drops.}

Rebound Hammer test was carried out on RC slabs randomly to evaluate the hardness/quality and strength of concrete in all the floors. From the results of the Rebound Hammer test, it is inferred that the estimated strength of concrete in the tested RC members is varying in the range $36 \mathrm{~N} / \mathrm{mm}^{2}$ to $44 \mathrm{~N} / \mathrm{mm}^{2}$ as per IS: 13311 - (Part-II)-1992(Reaffirmed in 2013).

c) Semi-Destructive tests to assess strength of in-situ concrete in columns, beams and slabs.

In order to assess the strength of in-situ concrete in columns, beams and slabs semi-destructive core test was adopted. The extracted core samples were subjected to compressive strength test after necessary trimming and capping as per the guidelines of IS:516-1959-(Reaffirmed in 2013). The grades of concrete found in the field after conducting tests in RC columns at different floors are as below:

Basement and Ground floor : M27

First floor

: M29

Second floor

: M28

Third and fourth floor : M32

Fifth and Sixth floor : M33

Seventh floor : M30

Eighth floor : : M33

Ninth floor : M27

The photographs of cracks, honeycombs and other distress observed in RC members of the existing building during site inspection and also the photographs of conducting NDT are as shown below:

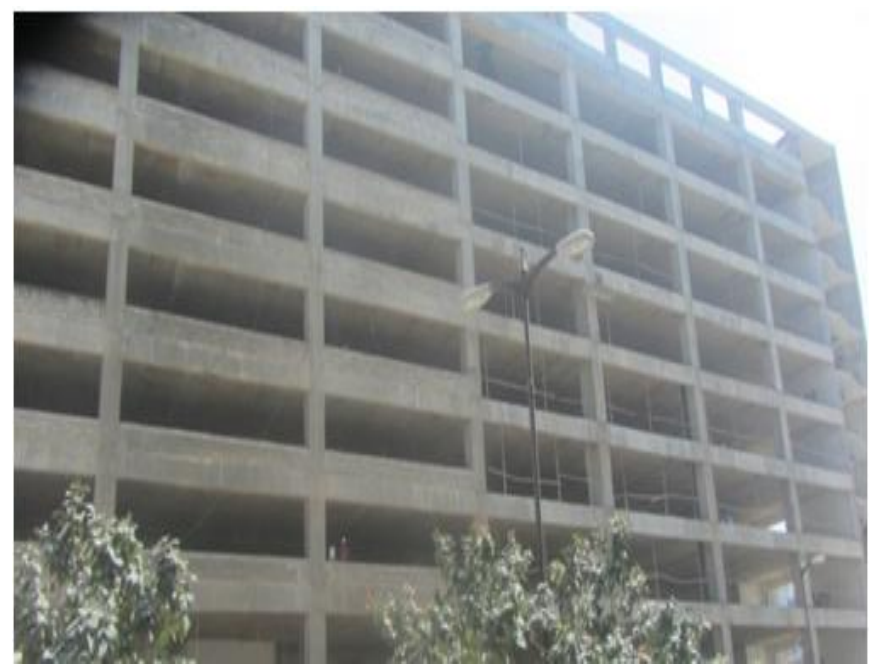

Fig 1 View of the building

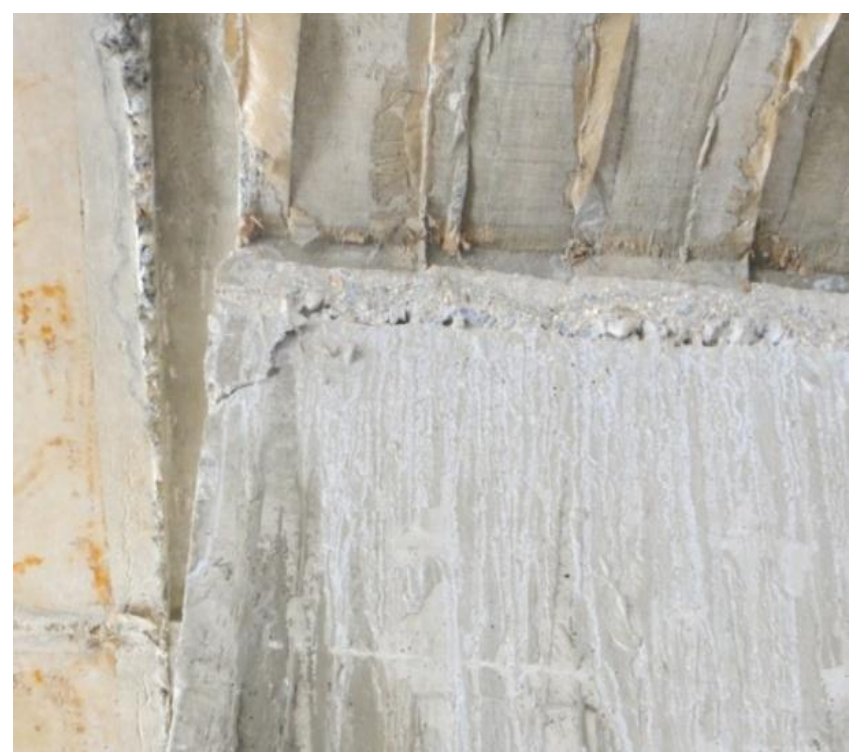

Fig 2 Honeycombed concrete 


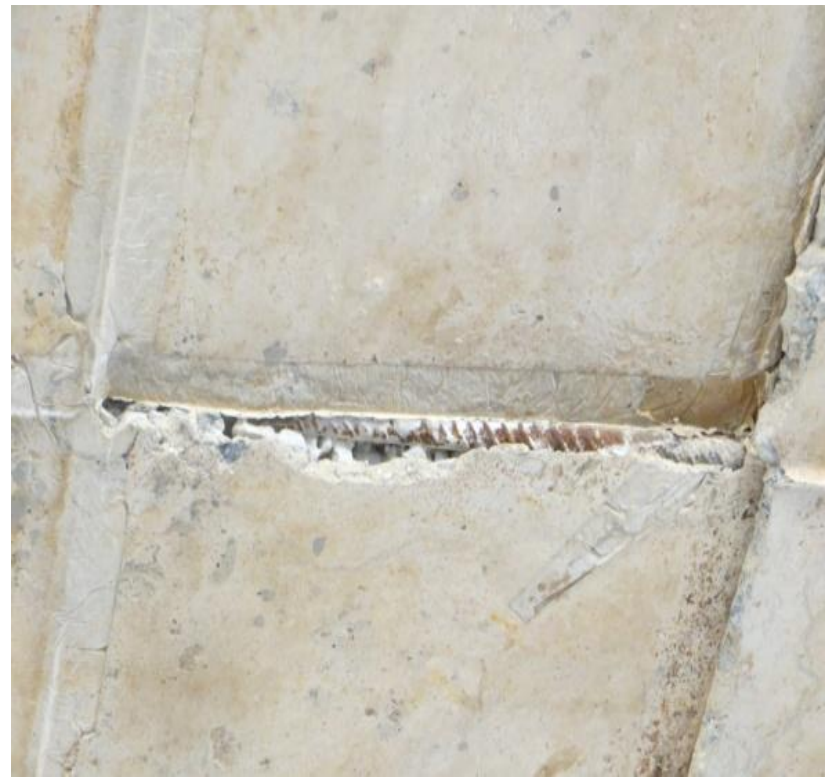

Fig 3 Exposure of reinforcement at column - beam junction

\section{THEORETICAL ANALYSIS \& DESIGN VERIFICATION}

An independent 3D analysis was carried out using software package ETABS 13.1.3. The structure was analyzed as a three dimensional frame for dead load, live load, seismic load, wind loads and their combinations.

The grades of concrete and reinforcing steel considered are as per design worked out during construction of the building.

Foundation: $\quad$ M25

Columns : M45 Foundation to second floor

M40 3rd to 4th floor

M35 5th to 6th floor

M30 7th floor to terrace

Beams/Slabs : $\quad$ M25

Further a theoretical analysis has been carried out by creating a model using ETABS software. From the analysis, it is observed that the existing structure is safe for designed grade of concrete and loads. Based on the field test results, another model for reduced grade of concrete which was used actually in the field during construction has been analyzed. From the analysis, it was seen that there was a lot of deficiency in the reinforcement in many of the RC columns, beams, slabs and drops at various levels of the structure. This indicates that the structure is not safe for existing loads. As there is a requirement of one additional floor over the existing structure, it was found to be not feasible. From the above considerations, it was recommended for the rehabilitation of the existing structure by strengthening deficient RC members in order to meet the required strength and also for the additional load of the required additional floor.

\section{RESULTS}

\subsection{RC Slabs, Column \& Beams Strengthening}

Details:

The deficiency in the structural members are made good by providing strengthening measures in the form of plate bonding, carbon wrapping and encasement in columns. Beams and slabs are strengthened by providing laminates. The typical details of the above strengthening measures are given below:

\section{For RC Columns:}

1. Concrete Encasement - 20 bars of $20 \varnothing$ and lateral ties $8 \varnothing @ 200 \mathrm{c} / \mathrm{c}$ with $12 \varnothing$ shear connectors at $600 \mathrm{c} / \mathrm{c}$ was proposed.

2. Plate Bonding - $600 \times 8 \mathrm{~mm}$ plate $\mathbf{3 0}$ of $\mathbf{1 2}$ dia bolts on both the faces of the column.(as per ACI 440.2R08)

3. Carbon Fibre Wrapping - 2 plies of $0.25 \mathrm{~mm}$ thick.(as per ACI 440.2R-08)

For RC Beams:

4. Carbon Laminates - 2 number of laminates of $1.4 \mathrm{~mm}$ thick along the length of the beam.(as per ACI 440.2R-08)

For RC Slabs:

5. Carbon Laminates - 2 number of laminates of $1.4 \mathrm{~mm}$ thick along both the directions.(as per ACI 440.2R-08)

\subsection{Strengthening Works in Progress}

The photographs of above strengthening works which were proposed are shown in the following figures:

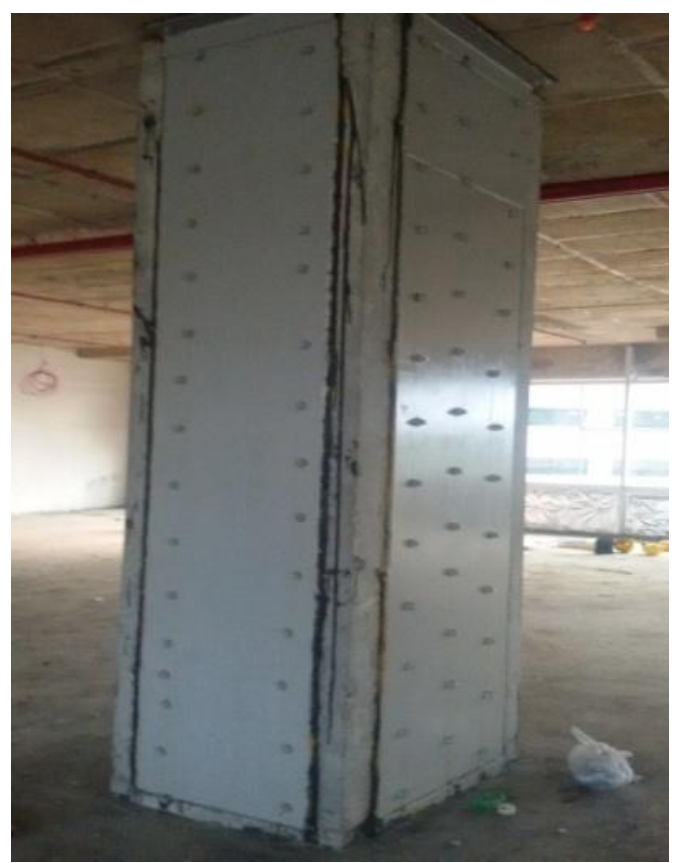

Fig 4 Column strengthened by plate bonding 


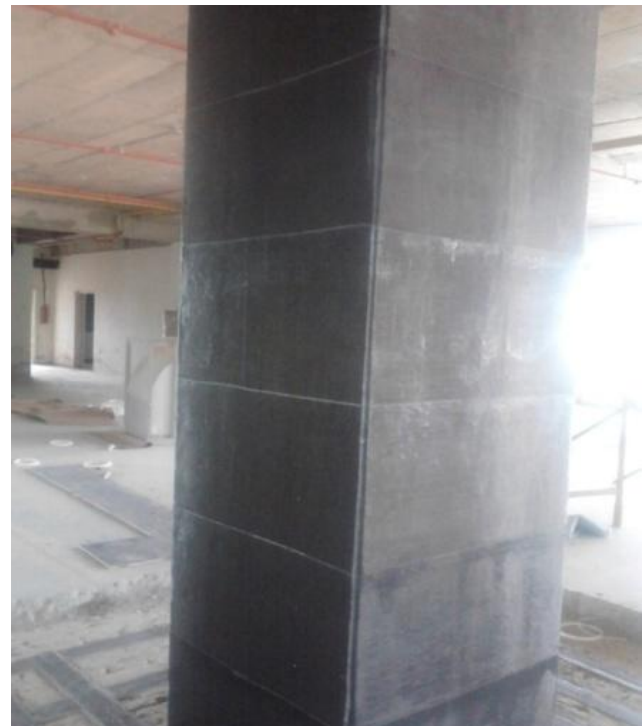

Fig 5 Column strengthened by carbon fiber wrapping

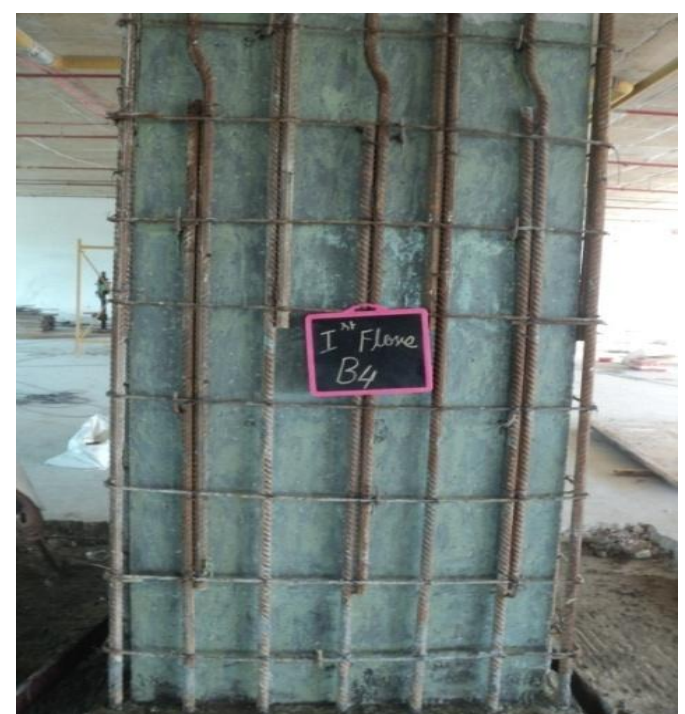

Fig 6 Reinforcement tied in place for column being strengthened by encasement

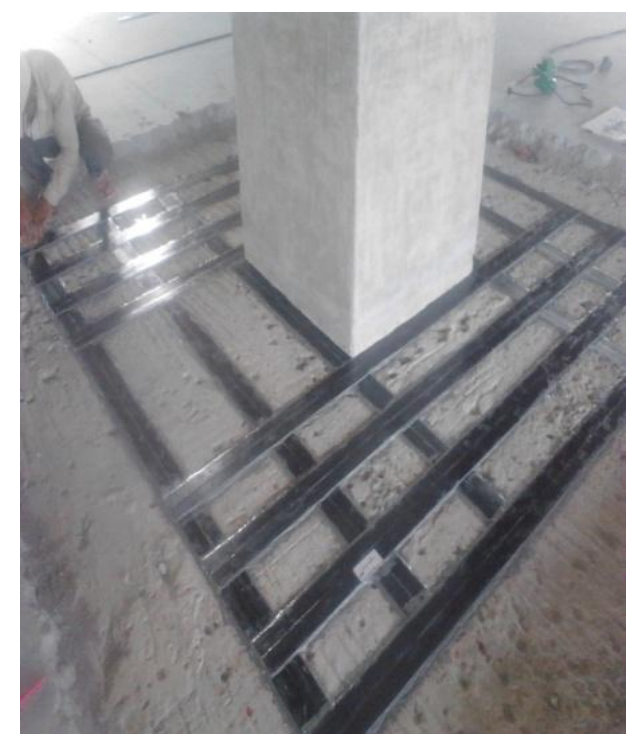

Fig 7 Slab Drop being strengthened by Laminates at top

\subsection{Comparative Study on Strengthening Measures}

In this project, study on strengthening measures has been made based on site constraints. The deficient RC columns of existing structure are strengthened by reinforced concrete encasement, carbon wrapping and plate bonding methods. A comparison study for RC column has been carried out on the above mentioned strengthening measures. Generally RC columns are subjected to major axial loading, it is required to have greater compressive strength and moment carrying capacity. All the above three strengthening measures however improves the stiffness and ductility in RC columns, but considering the factors like site constraints, ease of construction and availability of construction materials, these strengthening measures are adopted.

Concrete encasement is widely used for strengthening of RC columns. This method increases the compressive strength in RC columns and also improves the shear and flexural capacity of beams. The materials used for construction are also easily available and the method of construction is simple when compared to carbon wrapping and plate bonding methods. Thus concrete encasement has been recommended for most of the $\mathrm{RC}$ columns in the existing building. Based on the previous research and experimental study on carbon fiber wrapping method, it is observed to be very tedious method to handle and also economically costlier. But this method gives best results for square and circular columns. In the present project, this method has been recommended for few square columns especially in basement floor where existing parking space is not disturbed which could not achieved by concrete encasement.

In the existing structure, few deficient RC columns could not be strengthened either by Concrete Encasement or Carbon fiber wrapping. This is because all four sides of the column are not accessible to carry out the above two strengthening measures. These RC columns are strengthened by providing plate bonding method where deficiency has been improved by providing steel plates only on two accessible opposite faces of the existing columns. However RC slabs, beams and drops are recommended to be strengthened by providing appropriate number of laminates. Though concrete encasement could be easier method for strengthening of these RC members but in order to avoid additional encased dead weight of concrete in slabs and beams, strengthening by laminates are recommended.

\section{CONCLUSION}

The project brings out the following conclusions;

1. Structural information about the existing status are drawn.

2. Evaluation test of the existing structure turns out to be very essential.

3. The construction was found to be not compliant with the drawings and specifications given.

4. Improper construction practices were observed which caused minor cracks in RC members of the structure.

5. Improper shuttering work and workmanship during construction led to minor construction defects. 
6. The in situ concrete strength in RC columns was less compared to the design strength. The core test results indicated that the concrete grades in the existing structure were not as per design grades.

7. The existing "Prestige Excelsior" building is recommended to be rehabilitated for existing loads as per the theoretical analysis.

8. Construction of one additional floor over the existing structure was not feasible without strengthening the existing RC members of the structure.

9. After the strengthening of $\mathrm{RC}$ members of the existing building for the required deficiency of additional load, it was made feasible for the construction of one additional floor over the existing building.

10. The grades of concrete in the field for footing, slabs and beams were as per design.

11. Adequate strengthening measures are given to bring the building to normalcy for the proposed loads.

12. RC columns are proposed to be strengthened by encasement, carbon wrapping and plate bonding considering the site constraints in the existing building.

13. Slabs and beams are proposed to be strengthened by laminates.

\section{ACKNOWLEDGMENTS}

The authors wish to thank Civil Aid Techno Clinic Pvt. Ltd. This work was supported in part by a grant from Civil Aid Techno Clinic Pvt. Limited.

\section{REFERENCES}

[1] Handbook on Non Destructive Testing of Concrete Structures" International Atomic Agency, Vienna, 2002.

[2] Piotr Berkowski, Grzegorz Dmochowski, Marta Kosior-Kazberuk "Analysis of Structural and Material Degradation of a Car Park's RC Bearing Structure due to City Environmental Issues" $11^{\text {th }}$ International Conference on Modern Building Materials, Structures and Techniques, MBMST 2013.

[3] Lokesh V, B Shivkumara Swamy, S. Vijaya "Study on Soundness of Reinforced Concrete Structures by NDT Approach" International Journal \& Research in Engineering and Technology. eISSN:2319-1163 pISSN:2321-7308.

[4] "Testing of Concrete in Structures" $3^{\text {rd }}$ Edition by J.H.Bungey \& S.G.Millard.

[5] "Non-Destructive testing of concrete method of testUltrasonic pulse velocity", IS: 13311-(Part-1)-1992(Reaffirmed in 2004), Bureau of Indian standards, New Delhi.

[6] "Non-Destructive testing of concrete method of testRebound hammer", IS: 13311-(Part-2)-1992(Reaffirmed in 2004), Bureau of Indian standards, New Delhi.

[7] "Methods of Tests for Strength of Concrete" IS:5161959 (Reaffirmed in 2004).
[8] ACI Committee 214, Recommended Practice for Evaluation of Strength Test Results of Concrete (ACI 214-77), American Concrete Institute, Farmington Hills, Mich., 1977, 14pp.

[9] "Guide for the Design and Construction of Externally Bonded FRP Systems for Strengthening Concrete Structures" by ACI Committee 440. ACI 440.2R-08.

[10] Externally Bonded FRP Reinforcement for RC Structures fib TG 9.3

[11] IS 456:2000"Plain and reinforced concrete-code of practice"july 2000.

[12] IS 1893 (Part 1) : 2002 Criteria for Earthquake Resistant Design of Structures.

[13] IS 875 (Part 1) - 1987 Code of Practice for Design Loads(Other than Earthquake) for Buildings and Structures.

[14] IS 875 (Part 2) - 1987 Code of Practice for Design Loads(Other than Earthquake) for Buildings and Structures.

[15] IS 875 (Part 3) - 1987 Code of Practice for Design Loads(Other than Earthquake) for Buildings and Structures. 